\title{
High-efficiency infrared receiver
}

\author{
Esman A.K. ${ }^{1}$, Kostenko V.I. ${ }^{2}$, Mukhurov N.I. ${ }^{3}$, Zykov G.L. ${ }^{1}$, Potachits V.A. ${ }^{1}$ \\ ${ }^{1}$ Belarusian National Technical University, \\ Nezavisimosty Ave., 65, 220013, Minsk, Belarus \\ ${ }^{2}$ Space Research Institute of the Russian Academy of Sciences, \\ Profsoyuznaya st., 84/32, 117997, Moscow, Russia \\ ${ }^{3}$ State Scientific and Production Amalgamation "Optics, Optoelectronics and Laser Technology», \\ Nezavisimosty Ave., 68, 220072, Minsk, Belarus
}

Received 22.04.2016

Accepted for publication 08.08.2016

\begin{abstract}
Recent research and development show promising use of high-performance solid-state receivers of the electromagnetic radiation. These receivers are based on the low-barrier Schottky diodes. The approach to the design of the receivers on the basis of delta-doped low-barrier Schottky diodes with beam leads without bias is especially actively developing because for uncooled receivers of the microwave radiation these diodes have virtually no competition. The purpose of this work is to improve the main parameters and characteristics that determine the practical relevance of the receivers of mid-infrared electromagnetic radiation at the operating room temperature by modifying the electrodes configuration of the diode and optimizing the distance between them. Proposed original design solution of the integrated receiver of mid-infrared radiation on the basis of the low-barrier Schottky diodes with beam leads allows to effectively adjust its main parameters and characteristics. Simulation of the electromagnetic characteristics of the proposed receiver by using the software package HFSS with the basic algorithm of a finite element method which implemented to calculate the behavior of electromagnetic fields on an arbitrary geometry with a predetermined material properties have shown that when the inner parts of the electrodes of the low-barrier Schottky diode is performed in the concentric elliptical convex-concave shape, it can be reduce the reflection losses to $-57.75 \mathrm{~dB}$ and the standing wave ratio to 1.003 while increasing the directivity up to 23 at a wavelength of $6.09 \mu \mathrm{m}$. At this time, the rounded radii of the inner parts of the anode and cathode electrodes are equal $212 \mathrm{~nm}$ and $318 \mathrm{~nm}$ respectively and the gap setting between them is $106 \mathrm{~nm}$. These parameters will improve the efficiency of the developed infrared optical-promising and electronic equipment for various purposes intended for work in the mid-infrared wavelength range.
\end{abstract}

Keywords: electrodes of the elliptical convex-concave shape, reflection losses, voltage standing wave ratio, directivity.

DOI: $10.21122 / 2220-9506-2016-7-2-129-135$

\begin{tabular}{|c|c|}
\hline Адрес для переписки: & Address for correspondence: \\
\hline Есман А.К. & Esman A.K. \\
\hline Белорусский национальный технический университет, & Belarusian National Technical University, \\
\hline пр. Независимости, 65, 220013, г. Минск, Беларусь & Nezavisimosty Ave., 65, 220013, Minsk, Belarus \\
\hline e-mail:ak_esman@bntu.by & e-mail:ak_esman@bntu.by \\
\hline Для цитирования: & For citation: \\
\hline Esman A.K., Kostenko V.I., Mukhurov N.I., Zykov G.L., Potachits V.A. & Esman A.K., Kostenko V.I., Mukhurov N.I., Zykov G.L., Potachits V.A. \\
\hline High-efficiency infrared receiver. & High-efficiency infrared receiver. \\
\hline Приборы и методы измерений. & Pribory i metody izmerenij [Devices and Methods of Measurements]. \\
\hline 2016. - T. 7, № 2. - C. 129-135. & 2016 , vol. 7 , no. 2 , pp. $129-135$ \\
\hline DOI: $10.21122 / 2220-9506-2016-7-2-129-135$ & DOI: $10.21122 / 2220-9506-2016-7-2-129-135$ \\
\hline
\end{tabular}




\title{
Высокоэффективный приемник инфракрасного излучения
}

\author{
Есман А.К. ${ }^{1}$, Костенко В.И. ${ }^{2}$, Мухуров Н.И. ${ }^{3}$, Зыков Г.Л. ${ }^{1}$, Потачиц В.А. ${ }^{1}$ \\ ${ }^{1}$ Белорусский национальный технический университет, \\ пр. Независимости, 65, 220013, г. Минск, Беларусь \\ ${ }^{2}$ Институт космических исследований РАН, ул. Профсоюзная, 84/32, 117997, г. Москва, Россия \\ ${ }^{3}$ Государственное научно-производственное объединение «Оптика, оптоэлектроника и лазерная техника», \\ пр. Независимости, 68, 220072, г. Минск, Беларусь
}

Поступила 22.04.2016

Принята к печати 08.08.2016

Исследования и разработки последних лет показывают перспективность использования высокоэффективных твердотельных приемников электромагнитного излучения на основе низкобарьерных диодов Шоттки. Особенно активно развивается подход к конструированию приемников на основе $\delta$-легированных низкобарьерных диодов Шоттки с балочными выводами без смещения, так как для неохлаждаемых приемников микроволнового излучения у них практически нет конкурентов. Целью работы являлось улучшение основных параметров и характеристик, определяющих практическую востребованность приемников электромагнитного излучения среднего инфракрасного диапазона длин волн, работающих при температурах, близких к комнатной, за счет изменения конфигурации электродов диода и оптимизации расстояния между ними. Предложенное оригинальное конструктивное решение интегрального приемника среднего диапазона ИК-излучения на основе низкобарьерных диодов Шоттки с балочными выводами позволяет эффективно корректировать его основные параметры и характеристики. Моделирование электродинамических характеристик предложенного приемника, используя программный пакет HFSS, с базовым алгоритмом метода конечных элементов, реализованным для расчета поведения электромагнитных полей на произвольной геометрии с предварительно заданными свойствами материалов, показало: что при выполнении внутренних частей электродов низкобарьерного диода Шоттки в виде концентрической эллиптической выпукло-вогнутой формы можно достичь снижения потерь на отражение до $-57,75$ дБ и уменьшения коэффициента стоячей волны до 1,003 при одновременном увеличении коэффициента направленного действия до 23 на длине волны 6,09 мкм. При этом радиусы закруглений внутренних частей анодного и катодного электродов составляли 212 нм и 318 нм соответственно, а зазор между ними - 106 нм. Указанные параметры позволят повысить эффективность разрабатываемой инфракрасной перспективной оптико- и радиоэлектронной аппаратуры различного целевого назначения, предназначенной для работы в среднем инфракрасном диапазоне длин волн.

Ключевые слова: электроды эллиптической выпукло-вогнутой формы, потери на отражение, коэффициент стоячей волны, коэффициент направленного действия.

DOI: $10.21122 / 2220-9506-2016-7-2-129-135$

\begin{tabular}{|c|c|}
\hline $\begin{array}{l}\text { Адрес для переписки: } \\
\text { Есман А.К. } \\
\text { Белорусский национальный технический университет, } \\
\text { np. Независимости, 65, 220013, г. Минск, Беларусь } \\
\text { e-mail: ak_еsтап@bntu.by }\end{array}$ & $\begin{array}{l}\text { Address for correspondence: } \\
\text { Esman A.K. } \\
\text { Belarusian National Technical University, } \\
\text { NezavisimostyAve., 65, 220013, Minsk, Belarus } \\
\text { e-mail: ak_esman@bntu.by }\end{array}$ \\
\hline Для цитирования: & For citation: \\
\hline Esman A.K., Kostenko V.I., Mukhurov N.I., Zykov G.L., Potachits V.A. & Esman A.K., Kostenko V.I., Mukhurov N.I., Zykov G.L., Potachits V.A. \\
\hline High-efficiency infrared receiver. & High-efficiency infrared receiver. \\
\hline Приборы и методы измерений. & Pribory i metody izmerenij [Devices and Methods of Measurements]. \\
\hline 2016. - T. 7, № 2. - C. 129-135. & 2016 , vol. 7 , no. 2 , pp. $129-135$ \\
\hline DOI: $10.21122 / 2220-9506-2016-7-2-129-135$ & DOI: $10.21122 / 2220-9506-2016-7-2-129-135$ \\
\hline
\end{tabular}




\section{Introduction}

In recent years, special attention is given to research on the development and production of highperformance solid-state receivers of the infrared electromagnetic radiation. These receivers are based on the low-barrier Schottky diodes, which have virtually no competition in the uncooled microwave receivers $[1,2]$. This range of electromagnetic waves has attracted the attention of researchers both from theoretical and practical purposes due to its relevance in various fields of science and technology. The whole Planet Earth and all things therein, even the ice, emit the electromagnetic radiation located namely in this range $[3,4]$. The need to develop and produce the compact, inexpensive and reliable infrared facilities primarily relate to the expansion and deepening of space research. In the space it is almost ideal conditions for the propagation of infrared radiation, as there are no absorbing and scattering media. The practical relevance of the devices, that are based on these receivers, not only in the space industry, but also in biomedical applications, life safety systems, non-destructive testing systems, diagnostic systems of cancer diseases and many other areas [5-8].

The approach to the design of the receivers on the basis of $\delta$-doped low-barrier zero-bias Schottky diodes, which have beam leads $[9,10]$ and embed into the planar log-periodic and spiral (broadband) or dipole and slot antenna [11], is the most successful developed in this direction.

Upward frequency expansion of the operating band is difficult due to a number of significant limitations. The limit frequency of detection is determined on the one hand by the loss resistance and junction capacitance and on the other hand by the quality of the plates of the raw material, and the state of the art of technology and parasitic parameters depending on its design. Reducing the serial loss resistance by increasing the semiconductor doping is limited by achieved value of the dopant concentration [12]. Junction capacitance of the zerobias diode with an active region square of several square microns is currently equal to several $\mathrm{fF}$. One of the main parasitic parameters is stray capacitance of the diode, which is determined by the permittivity and the structure of the elastic dielectric disposed between the cathode and anode beam leads as well as their size and relative position.

However, the low efficiency of such receivers at room temperature prevents their wide use in practice [13-15], because when the widths of the contact and diode are equal to the microns fraction the edge effects have a considerable influence on the currentvoltage characteristics of a semiconductor junction, and the reduction of the width of the conducting lines, leaded to the contacts, related to the technical problems [16].

The purpose of this work is to improve the main parameters and characteristics of the integrated receiver of mid-infrared electromagnetic radiation at the operating room temperature by modifying the electrodes configuration of the diode and optimizing the distance between them.

\section{Receiver design}

In the paper we examined the correction method of the electric fields between the inner parts of the electrodes in the low-barrier Schottky diodes with the resonance nano- and microstructures. This method is based on the configuration modification of the inner parts of the metal electrodes, whose dimensions are less than the wavelength of the received electromagnetic radiation.

Known integral receiver [17] typically (Figure 1) comprises a substrate 1 , on which $\mathrm{n}^{+}$-layer 2, n-layer 3 and dielectric layer 4 with the cutout 13 sequentially deposited, and also includes a cathode 7 and anode 8 electrodes with the respective cathode (ohmic) 5 and anode (rectifying) 6 contacts in the layers 2 and 3. Elastic dielectric layer 9 is disposed over the electrodes 7 and 8 . It has a window 12 in the center and periodic holes symmetrically formed on its outer parts 10 . Resonance structures 11 in the form of nano- and micro-sized open-loop rectangular cavities located on the layer 9 at the perimeter of periodic apertures.

\section{Computer experiment}

Simulation of the electromagnetic characteristics of the proposed receiver was carried out in High Frequency Structure Simulator (HFSS) software package, which is the industry standard of the threedimensional solutions of the applications [18]. This software has a high accuracy, calculating speed and usability. Using advanced algorithms based on the finite element, integral equation and hybrid computational methods are implemented to calculate the behavior of 3D electromagnetic fields on the arbitrary geometry with predefined properties of materials. The hybrid computational method divides the problem into sub-areas, which can be calculated 
by using the finite element method, integral equation method and physical optics.

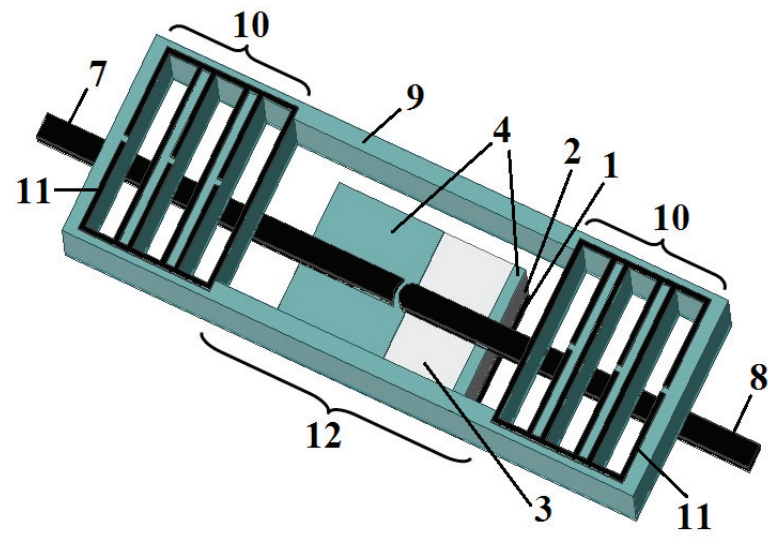

$a$

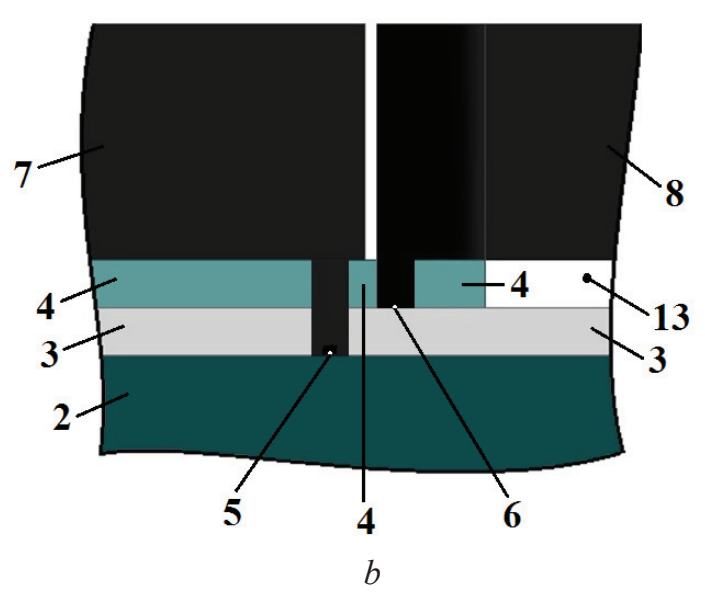

Figure 1 - The structure of IR receiver $(a)$ and the enlarged fragment of its section $(b)$ : 1 - substrate; $2-n^{+}$- layer; 3 - $n$-layer; 4 - dielectric layer; 5 - cathode contact; 6 - anode contact; 7 - cathode electrode; 8 - anode electrode; 9 - elastic dielectric layer; 10 - parts of the elastic dielectric layer with holes; 11 - nano- and micro-sized resonance structures; 12 - window; 13 - cutout

In the designed and implemented computer model the thickness of the substrate 1, n+-layer 2, n-layer 3 and the dielectric layer 4 made of silicon dioxide, respectively were: $1 \mu \mathrm{m}, 2 \mu \mathrm{m}, 0.1 \mu \mathrm{m}$ and $0.1 \mu \mathrm{m}$. The length and width of the substrate 1 and layers 2,3 and 4 of the Schottky diode was $4 \mu \mathrm{m} \times 3 \mu \mathrm{m}$. Layers 2 and 3 are made of gallium arsenide with bulk conductivities $143 \times 10^{3} \mathrm{~S} / \mathrm{m}$ and $45.45 \times 10^{3} \mathrm{~S} / \mathrm{m}$ respectively. Dimensions $(\mathrm{L} \times \mathrm{W} \times \mathrm{H})$ of the cutout 13 in the dielectric layer 4 under the electrode 8 are selected equal to $1.5 \times 3 \times 0.1 \mu \mathrm{m}$, and the dimensions of the golden electrodes 7 and 8 are equal to $15.25 \times 0.5 \times 0.5 \mu \mathrm{m}$. The gap between the inner parts of the electrodes was varied between 100 to $112 \mathrm{~nm}$.
We carried out calculation of the basic parameters and characteristics of the examined IR receiver for the inner parts of the electrodes 7 and 8 with the corresponding contacts 5 and 6 in a nonconcentric (Figure 2a) and concentric (Figure $2 b$ ) elliptic convex-concave shape. In the first case, the inner parts of the electrodes 7 and 8 with the corresponding contacts 5 and 6 are disposed along the axis of the electrodes relative to each other, and their rounded radii are equal. In the second case, the inner parts of the electrodes 7 and 8 with the corresponding contacts 5 and 6 are disposed along the axis of the electrodes relative to each other, and their rounded radii are different.

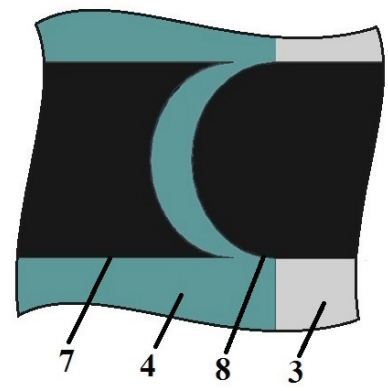

$a$

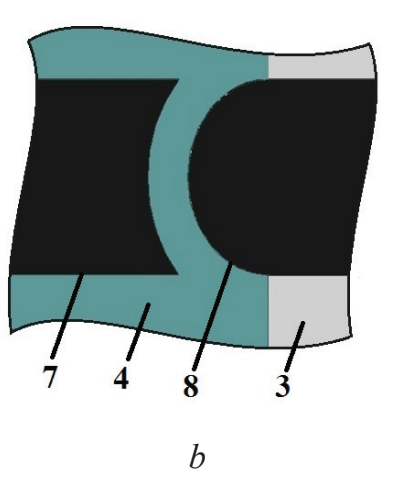

Figure 2 - Enlarged fragment (plane view) of the inner parts of the electrodes performed in a non-concentric $(a)$ and concentric $(b)$ elliptic convex-concave shape

Elastic dielectric layer 9 in the form of a polyimide plate has dimensions $\mathrm{L} \times \mathrm{W} \times \mathrm{H}$ : $12.25 \times 4.25 \times 2.5 \mu \mathrm{m}$. The length and width of nanoand micro-sized open-loop rectangular resonance structures 11, which made of gold and have a gap of $135 \mathrm{~nm}$, was equals 4.05 and $0.9 \mu \mathrm{m}$ respectively.

\section{Analysis of the results}

For examined configuration variants of the inner parts of the electrodes with the corresponding contacts, as well as for different values of the rounded radii of the inner parts and gaps settings between them, we calculated the reflection losses of the received infrared electromagnetic radiation, standing wave ratio (SWR) and the directivity.

The dependences of the reflection losses of the integrated receiver for the first and second cases on the rounded radius of the inner part of the anode electrode are shown in Figure 3. The dependence of the reflection losses of the integrated receiver for 
the second, as the most appropriate, case on the gap setting between the inner parts of the electrodes is shown in Figure 4.

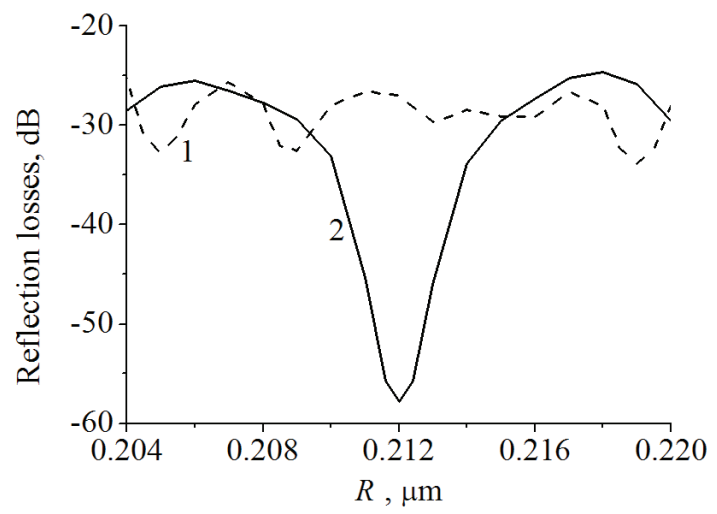

Figure 3 - The dependences of the reflection losses of the mid-infrared electromagnetic radiation receiver with the resonance nano- and microstructures on the rounded radius of the inner part of the anode electrode in a non-concentric (curve 1) and concentric (curve 2) elliptic convex shape relative to the inner part of the cathode electrode in an elliptic concave shape

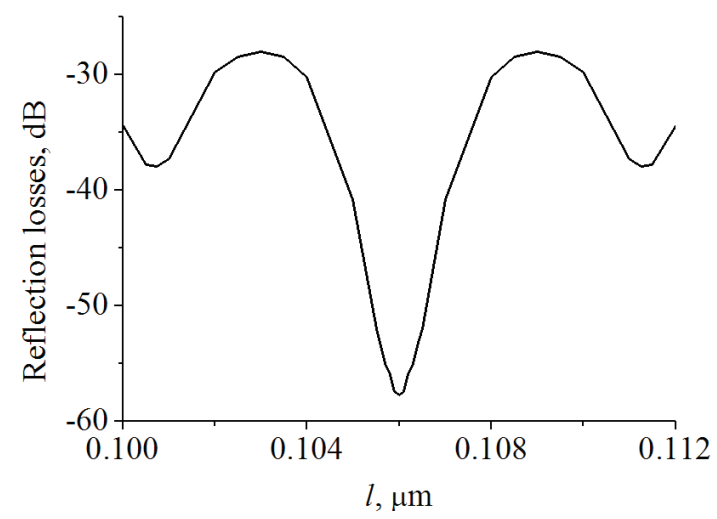

Figure 4 - The dependence of the reflection losses of the mid-infrared electromagnetic radiation receiver with the resonance nano- and microstructures on the gap setting between the inner parts of the electrodes in a concentric elliptic convex-concave shape

Analysis of the results shows that the optimal shape of the inner parts of the electrodes with the corresponding contacts, when the gap setting between the inner parts is equal $l=106 \mathrm{~nm}$, is concentric elliptic convex-concave shape with the rounded radius of the inner part of the anode electrode $R_{a}=212 \mathrm{~nm}$. At that, the rounded radius of the inner part of the cathode electrode $R_{c}=318 \mathrm{~nm}$ $\left(R_{c}=R_{a}+l\right)$.

The dependences of the reflection losses and SWR of the integrated receiver for the first (curves 1) and second (curves 2) cases and the case given in [17] (curves 3) for the same range of wavelengths of the electromagnetic radiation are shown in Figures 5 and 6.

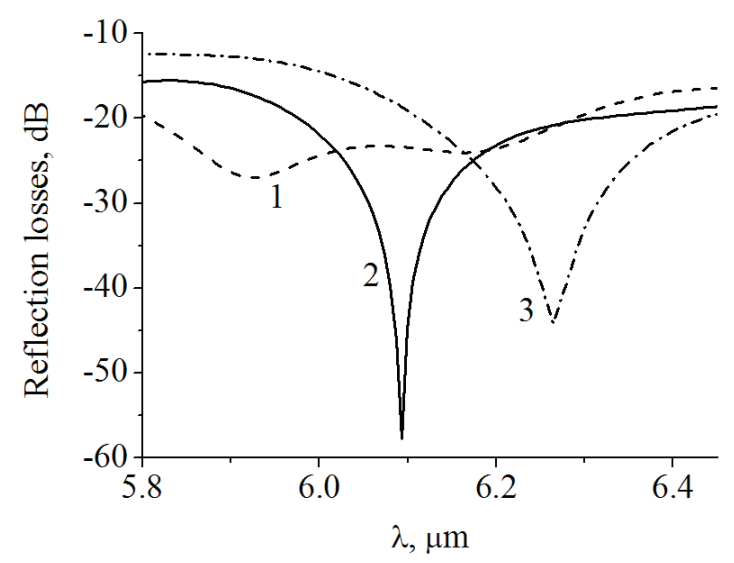

Figure 5 - The dependences of the reflection losses of the mid-infrared electromagnetic radiation receiver with the resonance nano- and microstructures on the wavelength for the first (curve 1) and second (curve 2) cases and the case given in [17] (curve 3)

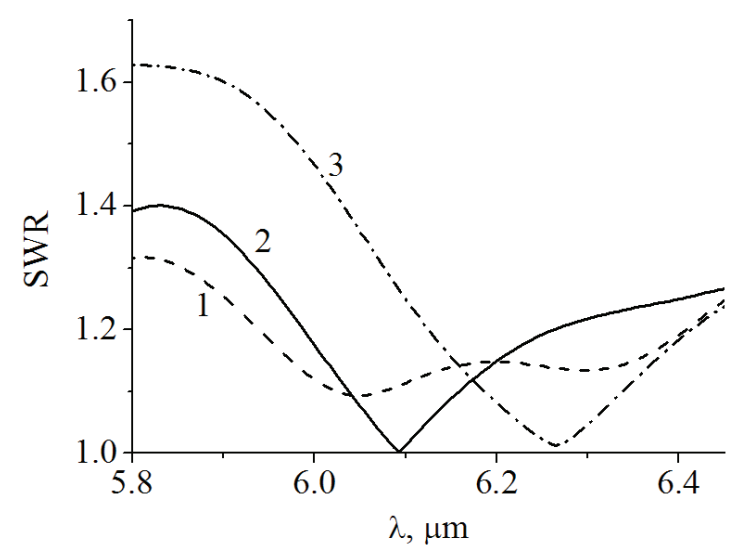

Figure 6 - The dependences of the ratio standing wave of the mid-infrared electromagnetic radiation receiver with the resonance nano- and microstructures on the wavelength for the first (curve 1) and second (curve 2) cases and the case given in [17] (curve 3)

According to the carried out calculations, the minimum reflection losses are equal -26.99 , -57.75 and $-44.15 \mathrm{~dB}$ (curves 1, 2 and 3, Figure 5), respectively, at wavelengths of 5.93, 6.09 and $6.26 \mu \mathrm{m}$. The minimum SWR are respectively 1.094, 1.003 and 1.012 (curves 1, 2 and 3, Figure 6) on the same wavelength.

Analysis of the results shows that the implementation of the inner parts of the electrodes with the corresponding contacts in a concentric elliptic convex-concave shape allow to reduce the reflection losses to $-57.75 \mathrm{~dB}$ and the SWR to 1.003 . 
Moreover, the calculation of the direction pattern shows that the directivity for the above-mentioned case is improved, i.e. it reaches about 23 (Figures 7 and 8).

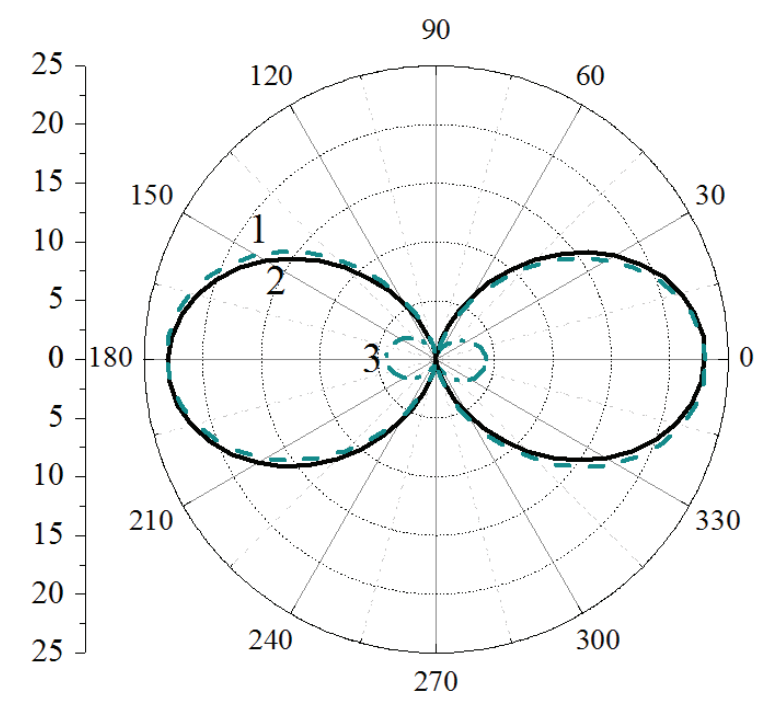

Figure 7 - Directivity pattern of the mid-infrared electromagnetic radiation receiver with the resonance nano- and microstructures on the azimuthal angle at the elevation angle $\theta=180$ degrees for the first (curve 1) and second (curve 2) cases and the case given in [17] (curve 3)

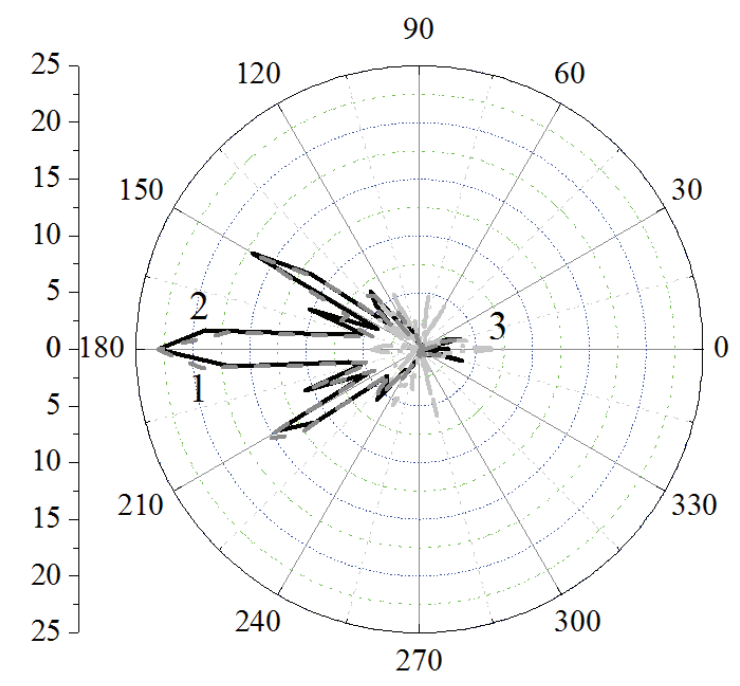

Figure 8 - Directivity pattern of the mid-infrared electromagnetic radiation receiver with the resonance nano- and microstructures on the elevation angle at the azimuthal angle $\varphi=90$ degrees for the first (curve 1) and second (curve 2) cases and the case calculated for [17] (curve 3)

\section{Conclusion}

By numerical methods we studied the effect of the electrodes configuration and the distance between them in the low-barrier Schottky diodes on the main parameters and characteristics that determine practical suitability of receivers of midinfrared electromagnetic radiation.

We have shown that by modifying the configuration of the inner parts of the electrodes it can be effectively adjust the main parameters and characteristics of the infrared receivers based on the low-barrier Schottky diodes. In particular, when the inner parts of the electrodes is performed in a concentric elliptic convex-concave shape we achieved a reduction of the reflection losses to $-57.75 \mathrm{~dB}$ and the standing wave ratio to 1.003 while increasing the directivity up to 23 at a wavelength of $6.09 \mu \mathrm{m}$. At that, the rounded radii of the inner parts of the anode and cathode electrodes are equal $212 \mathrm{~nm}$ and $318 \mathrm{~nm}$ respectively and the gap setting between them is $106 \mathrm{~nm}$.

Examined infrared receiver can improve the operating efficiency of the developed promising infrared optical and electronic equipment for various purposes.

\section{References}

1. Sydlo C., Cojocari O., Schonherr D., Goebel T., Meissner P., Hartnagel H.L. Fast THz detectors based on InGaAs Schottky diodes. Frequenz, 2008, vol. 62, no. 5-6, pp. 107-110.

2. Ferguson B., Zhang X.-C. Materials for terahertz science and technology. Nature Materials, 2002, no. 1, pp. 26-33.

3. Pierrehumbert R.T. Infrared radiation and planetary temperature. Physics Today, 2011, vol. 64, iss. 1, pp. 33-38.

4. Pupeza I., Sanchez D., Zhang J., Lilienfein N., Seidel M., Karpowicz N., Paasch-Colberg T., Znakovskaya I., Pescher M., Schweinberger W., Pervak V., Fill E., Pronin V., Wei F., Krausz F., Apolonski A., Biegert J. High-power sub-two-cycle mid-infrared pulses at $100 \mathrm{MHz}$ repetition rate. Nature Photonics, 2015, vol. 9 , no. 11, pp. $721-724$.

5. Vatansever F., Hamblin M.R. Far infrared radiation (FIR): its biological effects and medical applications. Photonics and Lasers in Medicine, 2012, no. 4, pp. 255-266.

6. Sigrist M.W. Mid-infrared laser-spectroscopic sensing of chemical species, Journal of Advanced Research, 2015, vol. 6, iss. 3, pp. 529-533.

7. Rettich F., Vieweg N., Cojocari O., Deninger A. Field intensity detection of individual terahertz pulses at $80 \mathrm{MHz}$ repetition rate. Journal of Infrared, Millimeter, and Terahertz Waves, 2015, vol. 36, iss. 7, pp. 607-612.

8. Vaks V.L., Anfertev V.A., Goltsman G.N., Pentin I.V., Tretyakov I.V. [High resolution terahertz spectrometer based on nanostructured semiconductor 
and superconductor devices]. Zhurnal radioelektroniki [Journal of Radio Electronics]. 2016, no. 1, pp. 54-63 (in Russian).

9. Shashkin V.I., Murel' A.V. Diagnostics of lowbarrier Schottky diodes with near-surface $\delta$-doping. Semiconductors, 2008, vol. 42, iss. 4, pp. 490-492.

10. Sassen S., Witzigmann B., Wolk C., Brugger H. Barrier height engineering on GaAs THz Schottky diodes by means of high-doping, InGaAs- and InGaP-layers. IEEE Transaction on Electron Devices, 2000, vol. 47, pp. 24-32.

11. Brown E.R. A system-level analysis of Schottky diodes for incoherent $\mathrm{THz}$ imaging arrays. Solid-State Electronics, 2004, vol. 48, iss. 10-11, pp. 2051-2053.

12. Maiwald F., Lewen F., Ahrens V., Beaky M., Gendriesch R., Koroliev A.N., Negirev A.A., Vowinkel G., Winnewisser G. Pure rotational spectrum of $\mathrm{HCN}$ in the terahertz region: use of a new planar Schottky diode multiplier. Journal of Molecular Spectroscopy, 2000, vol. 202, iss. 1, pp. 166-168.

13. Kosyachenko L.A., Markov A.V., Ostapov S.E., Rarenko I.M., Sklyarchuk V.M., Sklyarchuk Ye.F. Electrical properties of narrow-gap HgMnTe Schottky diodes. Semiconductors, 2002, vol. 36, iss. 10, pp. 11381145 .
14. Shevchik-Shekera A.V. [Real and limit sensitivity of some radiation detectors of $\mathrm{THz} / \mathrm{sub}-\mathrm{THz}$ ranges]. Tekhnologiya i konstruirovaniye v elektronnoy apparature [Technology and design in electronic equipment]. 2012, no. 1, pp. 3-6 (in Russian).

15. Kazemi H., Shinohara K., Nagy G., Ha W., Lail B., Grossman E., Zummo G, Folks W.R., Alda J., Boreman G. First THz and IR characterization of nanometer-scaled antenna-coupled InGaAs/InP Schottky-diode detectors for room temperature infrared imaging. Proc. of SPIE, 2007, vol. 6542, pp. 65421J-1-4.

16. Zakamov V.R., Chechenin Y.I., Pryakhin D.A., Yurasov D.V. [Low-barrier Schottky diode on silicon wafers with lateral structure]. Uspekhi Prikladnoi Fiziki [Advances in Applied Physics]. 2013, vol. 1, no. 1, pp. 97104 (in Russian).

17. Esman A.K., Kuleshov V.K., Zykov G.L., Zalesski V.B. [Infrared detector on the basis of the Schottky junction with the resonance nano- and microstructures]. Nano- $i$ mikrosistemnaya tekhnika [Journal of Nano and Microsystem Technique]. 2014, no. 3, pp. 44-46 (in Russian).

18. Bankov S.E., Guttsayt E.M., Kurushin A.A. Reshenie opticheskikh i SVCh zadach s pomoshch'yu HFSS [The solution of optical and microwave problems using HFSS]. Moscow, Orkada Publ., 2012. 250 p. 